\title{
ASSAY OF TYPHOID VACCINES IN MICE
}

\author{
M. STERNE AND GladYs TRIM \\ Wellcome Research Laboratories, Beckenham, Kent
}

NONE of the laboratory tests suggested for assaying typhoid vaccines can be claimed-with much confidence-to reflect results in the field. This lack of a test to distinguish the poor batch from the indifferent is of some consequence, because of the comparative ineffectiveness of typhoid vaccines to confer more than a marginal herd immunity, and because their use is not devoid of risk.

The World Health Organization has enumerated laboratory tests that have been recommended from time to time, and Joó, Pusztai and Juhász (1968) have emphasised the difficulty of accepting that any of these procedures reflect the worth of a vaccine. Whilst the World Health Organization has refrained from recommending any laboratory test in mice, the United States Department of Health (1969) has prescribed a particular test procedure and provided a standard vaccine against which typhoid vaccines sold in the United States must be assayed. This test requires intraperitoneal vaccination followed 7-14 days later by challenge with virulent typhoid organisms incorporated in 5\% hogs' gastric mucin (procedure 1P7-14M in Joós notation).

The selection of this procedure was due mainly to the observation of Pittman and Bohner (1966) that acetone-killed suspensions protected mice better against challenge than did heat-killed suspensions when inoculations were made intraperitoneally rather than subcutaneously. Because acetonekilled typhoid vaccines were considered to have been more effective in the field, the United States authorities believed that use of the intraperitoneal route for the statutory assay would better reflect the ranking of the two kinds of vaccine in the field.

It is well known that protection against challenge may be very greatly enhanced by non-specific factors, particularly after intraperitoneal vaccination (Sterne and Trim, 1968, 1970). We also suggested that the prominent peak in immunity noted about 4 days after intraperitoneal or subcutaneous vaccination was due to non-specific stimulation (Sterne and Trim, 1971). Experiments reported here have caused us to modify these views and tend to confirm Landy's contention that protection in mice can be almost entirely ascribed to Vi antigen, which is not considered significant in the protection of man.

\section{MATERIALS AND METHODS}

Vaccines

Batch V980: a suspension of Salmonella typhi strain Ty2 killed by heat and phenol and lyophilised.

Received 8 Mar. 1973; accepted 17 Aug. 1973.

J. MED. MICROBIOL.-VOL. 7 (1970) 
Batch MSt33: a suspension of $S$. typhi Ty2 grown in continuously dialysed medium (Sterne, 1958), precipitated, killed with acetone, and lyophilised.

Batch MSt54: a suspension of $S$. typhi Ty2 precipitated, killed with acetone, and lyophilised.

Batch MC8A: a suspension of Escherichia coli (Vi-producing strain "opaque 36 " from Professor E. E. Baker, Boston University) killed with alcohol, dried with acetone, redispersed in an aqueous solution, and lyophilised.

$W H O / K$ : acetone-killed, lyophilised International Reference Preparation of typhoid vaccine.

WHO/L: heat phenol-killed, lyophilised International Reference Preparation of typhoid vaccine.

US6A: acetone-killed, lyophilised United States Typhoid Vaccine Standard.

Batch XSt72: S. typhi Ty2 grown in continuously dialysed medium. The living culture was treated with sodium dodecyl sulphate and centrifuged, and the precipitate was extracted with saline. This extract was precipitated with ethyl alcohol and the precipitate dissolved in physiological saline and lyophilised.

Batch XC90: an extract prepared from acetone-killed E. coli strain 136 by the method of Esposito and Feeley (1970) for preparing pure Vi antigen.

\section{Bacterial counts}

The organisms in suspensions were counted in a Helber chamber by dark field illumination.

\section{Challenge}

The strain of $S$. typhi Ty2 was $\mathrm{H}$ and $\mathrm{O}$ positive and inagglutinable by $\mathrm{O}$ antisera. The live suspension was held in liquid nitrogen in a mixture of $1 \%$ Casamino Acids and $10 \%$ dimethylsulphoxide. To prepare the challenge, an ampoule was thawed and the suspension diluted to the required number of organisms in 5\% hogs' gastric mucin in $1 \%$ Casamino Acids. The LD50 was usually about $3 \times 10^{6}$ organisms when suspended in Casamino Acids and 1-10 organisms when incorporated in mucin. The viable count and the LD50 were checked in each experiment.

\section{Test procedure}

Mice. Schofield white Swiss females weighing 16-20 g.

Vaccination. To determine the ED50, four or more dilutions of the suspensions or extracts under investigation were made at five-fold intervals in physiological saline and $0.5 \mathrm{ml}$ of each dilution was injected into each mouse in a group of 16 . An assay normally required 64 mice per preparation. Vaccines were injected subcutaneously (SC) or intraperitoneally (IP) as noted in the tables and the mice were challenged (IP) at the times indicated with approximately 200 LD50 of the Ty2 suspension contained in $0.5 \mathrm{ml}$ of $5 \%$ mucin. They were observed for 4 days.

\section{RESULTS}

The relative efficacies of different types of vaccine after subcutaneous or intraperitoneal inoculation and challenge with virulent $S$. typhi incorporated in mucin (procedures SCM and IPM)

The results (table I) broadly confirmed those of Pittman and Bohner (1966). The ratios of the relative potencies after subcutaneous vaccination to those after intraperitoneal vaccination were $1 \cdot 8,1 \cdot 2$, and 1.0 for the acetone-killed vaccines MSt33, WHO/K, and US6A respectively, and 0.6 and 0.1 for the heatkilled vaccines $\mathrm{V} 980$ and $\mathrm{WHO} / \mathrm{L}$ respectively. The most extreme ratio was 
shown by vaccine MC8A, an acetone-killed suspension of $E$. coli, which was amongst the most effective of the vaccines after intraperitoneal inoculation, but by far the poorest after subcutaneous. It thus exhibited in an extreme form those characteristics of acetone-killed typhoid suspensions that are considered to justify using the IPM in preference to the SCM procedure for assay. An extract (XSt72) of $S$. typhi consisting mainly of " Vi" antigen showed the least difference between the responses to the two procedures, confirming the observation of Landy (1957) that the response to " $\mathrm{Vi}$ " antigen was independent of the route of administration.

TABLE I

The relative efficacies of different types of vaccine when assayed by procedures SCM or IPM

\begin{tabular}{|c|c|c|c|c|c|c|c|c|c|}
\hline \multirow[t]{2}{*}{$\begin{array}{l}\text { Vaccine } \\
\text { batch }\end{array}$} & \multirow[t]{2}{*}{$\begin{array}{l}\text { Prepared } \\
\text { from }\end{array}$} & \multirow[t]{2}{*}{$\begin{array}{c}\text { How } \\
\text { inactivated }\end{array}$} & \multicolumn{2}{|c|}{$\begin{array}{l}\text { Number of } \\
\text { valid tests }\end{array}$} & \multicolumn{2}{|c|}{$\begin{array}{l}\text { Mean number of } \\
\text { organisms corresponding } \\
\text { to ED50 }\left(10^{6}\right) \text { in }\end{array}$} & \multicolumn{2}{|c|}{$\begin{array}{l}\text { Relative } \\
\text { potency by }\end{array}$} & \multirow[t]{2}{*}{$b / a$} \\
\hline & & & $\mathrm{SCM}$ & IPM & SCM & IPM & SCM(a) & $\operatorname{IPM}(b)$ & \\
\hline $\begin{array}{l}\text { V980 } \\
\text { WHO/L } \\
\text { MSt33 } \\
\text { WHO/K } \\
\text { US6A } \\
\text { XSt72 }\end{array}$ & $\begin{array}{l}\text { S. typhi Тy2 } \\
\text { S. typhi Ty2 } \\
\text { S. typhi Ty2 } \\
\text { S.tpphi Ty2 } \\
\text { S. typhi Ty2 } \\
\text { S.typhi Ty2 } \\
\text { (Vi extract) }\end{array}$ & $\begin{array}{l}\text { Heat-phenol } \\
\text { Heat-phenol } \\
\text { Acetone } \\
\text { Acetone } \\
\text { Acetone } \\
\text {... }\end{array}$ & $\begin{array}{r}14 \\
1 \\
6 \\
2 \\
1 \\
5\end{array}$ & $\begin{array}{r}11 \\
3 \\
8 \\
5 \\
3 \\
3 \\
8\end{array}$ & $\begin{array}{c}12 \cdot 1 \pm 8 \cdot 8 \\
4 \cdot 9 \\
12 \cdot 0 \pm 4 \cdot 2 \\
4 \cdot 3 \\
3 \cdot 8 \\
3 \cdot 0 \pm 2 \cdot 1\end{array}$ & $\begin{array}{l}0.46 \pm 0.44 \\
1.06 \\
0.16 \pm 0.06 \\
0.09 \pm 0.05 \\
0.09 \\
1.10 \pm 0.05\end{array}$ & $\begin{array}{r}3.8 \\
8.5 \\
3.8 \\
9 \cdot 7 \\
11.0 \\
13.9\end{array}$ & $\begin{array}{c}2 \cdot 4 \\
1 \\
7 \\
12 \\
12 \\
1\end{array}$ & $\begin{array}{l}0.6 \\
0.1 \\
1.8 \\
1.2 \\
1.0 \\
0.07\end{array}$ \\
\hline MC8A & E. coli & Acetone & 2 & 3 & $41 \cdot 7$ & $0 \cdot 13$ & 1 & 8 & $8 \cdot 0$ \\
\hline
\end{tabular}

SCM = Assay after vaccination by subcutaneous injection; IPM = assay after vaccination by intraperitoneal injection.

\section{The effect of different intervals between vaccination and challenge}

We showed (Sterne and Trim, 1968) that a precocious non-specific protection against challenge with virulent $S$. typhi could be induced in mice by killed suspensions of heterologous organisms-Bordetella pertussis, Brucella abortus. Protection was as evident after subcutaneous as after intraperitoneal inoculation. Later (Sterne and Trim, 1970) it was shown that calcium alginate added to typhoid vaccine markedly increased its ability to elicit immunity after intraperitoneal but not after subcutaneous inoculation. Calcium alginate also enhanced the non-specific protection induced by killed suspensions of heterologous organisms.

Because the protection of mice against challenge with virulent $S$. typhi could so readily be induced and also enhanced by non-specific mechanisms, it was essential to establish how much of the immunity elicited in mice by typhoid vaccines was a response to factors irrelevant to protection in man. To investigate the early induction of protection in mice against typhoid, experimentssummarised in table II-were performed to follow the rate of immunity induced by different types of vaccine inoculated either intraperitoneally or subcutaneously.

The vaccines tested included a heat-killed (V980) and an acetone-killed (MSt33) suspension of $S$. typhi Ty2; an extract of $S$.typhi Ty2 (XSt72) consisting 
TABLE II

Development of protection after the inoculation of different types of vaccine either intraperitoneally or subcutaneously

\begin{tabular}{|c|c|c|c|c|c|c|c|c|c|c|c|}
\hline \multirow{3}{*}{$\begin{array}{l}\text { Vaccine batch } \\
\text { and type }\end{array}$} & \multirow{3}{*}{$\begin{array}{l}\text { Route of } \\
\text { injection }\end{array}$} & \multicolumn{10}{|c|}{$\begin{array}{c}\text { Mean number of organisms (with range) corresponding to ED50(10\%), and relative potency (RP) on } \\
\text { indicated day after vaccination }\end{array}$} \\
\hline & & \multicolumn{2}{|c|}{1 day } & \multicolumn{2}{|c|}{2 days } & \multicolumn{2}{|l|}{4 days } & \multicolumn{2}{|l|}{8 days } & \multicolumn{2}{|c|}{18 days } \\
\hline & & ED50 & $\mathbf{R P}$ & ED50 & $\mathbf{R P}$ & ED50 & $\mathbf{R P}$ & ED50 & $\mathbf{R P}$ & ED50 & $\mathbf{R} \mathbf{P}$ \\
\hline \multirow[t]{2}{*}{$\begin{array}{l}\text { S. typhi } \\
\text { V980, heat-phenol }\end{array}$} & $\underset{\text { SP }}{\text { IP }}$ & 200 & $\begin{array}{l}<0.01 \\
<0.01\end{array}$ & $\begin{array}{l}0.6 \\
3 \cdot 4\end{array}$ & $\begin{array}{l}1 \\
4\end{array}$ & $\begin{array}{l}0.01 \\
0.90\end{array}$ & 58 & \multirow{2}{*}{$\begin{array}{c}0 \cdot 02 \\
2 \cdot 2 \\
(0 \cdot 2-3 \cdot 6) \\
1 \cdot 2 \\
(0 \cdot 6-2 \cdot 3)\end{array}$} & $\begin{array}{r}23 \\
7\end{array}$ & $\begin{array}{r}0.4 \\
14 \cdot 7\end{array}$ & $\stackrel{1 \cdot 4}{1}$ \\
\hline & SC & 400 & $<0.01$ & 3.9 & 2 & $\begin{array}{c}0 \cdot 60 \\
(0 \cdot 4-1 \cdot 2)\end{array}$ & 13 & & 6 & $\begin{array}{c}7 \cdot 7 \\
(4 \cdot 3-13 \cdot 5)\end{array}$ & 1 \\
\hline \multirow{2}{*}{$\begin{array}{l}\text { S. typhi } \\
\text { MSt33, acetone }\end{array}$} & IP & $>100$ & $<0.01$ & \multirow{2}{*}{$\begin{array}{c}0.8 \\
(0 \cdot 6-1 \cdot 2) \\
14 \cdot 0\end{array}$} & 1 & 0.001 & 100 & \multirow{2}{*}{$\begin{array}{c}0.05 \\
(0 \cdot 01-0 \cdot 11) \\
9 \cdot 4 \\
(4 \cdot 8-18 \cdot 0)\end{array}$} & 15 & \multirow{2}{*}{$\begin{array}{c}0 \cdot 12 \\
(0 \cdot 04-0 \cdot 2) \\
38 \cdot 0 \\
(17-395)\end{array}$} & 6 \\
\hline & SC & $>200$ & $<0.01$ & & 3 & $1 \cdot 1$ & 20 & & 6 & & 1 \\
\hline \multirow{2}{*}{$\begin{array}{l}\text { S. typhi } \\
\text { XSt72, Vi extract }\end{array}$} & IP & $>100$ & $<0.01$ & \multirow{2}{*}{$\begin{array}{c}0.4 \\
(0 \cdot 2-0 \cdot 7) \\
2 \cdot 8\end{array}$} & 2 & $0 \cdot 1$ & 7 & \multirow{2}{*}{$\begin{array}{c}0 \cdot 6 \\
(0 \cdot 3-1 \cdot 1) \\
0 \cdot 4\end{array}$} & $1 \cdot 3$ & \multirow{2}{*}{$\begin{array}{c}0 \cdot 7 \\
(0 \cdot 4-1 \cdot 3) \\
11 \cdot 7 \\
(6-24)\end{array}$} & 1 \\
\hline & SC & $>500$ & $<0.01$ & & $2 \cdot 5$ & $(0.2-0.8)$ & 25 & & 11 & & 1 \\
\hline \multirow{3}{*}{$\begin{array}{l}E . \text { coli } \\
\text { MC8A, acetone }\end{array}$} & IP & 32 & 0.01 & \multirow{3}{*}{$\begin{array}{c}0.31 \\
(0 \cdot 2-0 \cdot 6) \\
0 \cdot 5 \\
(0 \cdot 3-0 \cdot 8) \\
27 \cdot 0 \\
25 \cdot 0\end{array}$} & 1 & $\begin{array}{c}0.004 \\
(0.002-0.01\end{array}$ & 69 & \multirow{3}{*}{$\begin{array}{c}0.02 \\
(0.01-0.04) \\
0.03 \\
(0.0005-0.058) \\
28 \cdot 0 \\
6.8 \\
(5 \cdot 0-13)\end{array}$} & 17 & \multirow{3}{*}{$\begin{array}{c}0.22 \\
(0 \cdot 1-0.4) \\
0.2 \\
(0.1-0.4) \\
29 \cdot 0 \\
22 \cdot 0 \\
(12-39)\end{array}$} & $1 \cdot 4$ \\
\hline & IP & $>100$ & $<0.01$ & & 1 & 0.01 & 16 & & 11 & & $1 \cdot 4$ \\
\hline & $\begin{array}{l}\text { SC } \\
\text { SC }\end{array}$ & $\begin{array}{l}500 \\
100\end{array}$ & $\begin{array}{l}<0.01 \\
<0.01\end{array}$ & & ${ }_{1}^{1 \cdot 1}$ & $\begin{array}{c}1 \cdot 5 \\
1 \cdot 5 \\
(1 \cdot 0-3 \cdot 0)\end{array}$ & $\begin{array}{l}20 \\
16\end{array}$ & & $\frac{1}{3 \cdot 7}$ & & $\begin{array}{l}1 \\
1 \cdot 1\end{array}$ \\
\hline $\begin{array}{l}E \cdot \text { coli } \\
\text { XC90, Vi extract }\end{array}$ & $\begin{array}{l}\text { IP } \\
\text { SC }\end{array}$ & $\begin{array}{r}800 \\
1600\end{array}$ & $\begin{array}{l}<0.01 \\
<0.01\end{array}$ & $\begin{array}{l}1 \\
4\end{array}$ & $\begin{array}{l}5 \\
2\end{array}$ & $\begin{array}{l}0.02 \\
1 \cdot 3\end{array}$ & $\begin{array}{r}50 \\
6\end{array}$ & $\begin{array}{l}1 \\
4\end{array}$ & $\begin{array}{l}5 \\
2\end{array}$ & $\begin{array}{l}5 \\
2\end{array}$ & $\begin{array}{l}1 \\
1\end{array}$ \\
\hline
\end{tabular}

IP $=$ Intraperitoneal ; SC $=$ subcutaneous. 
mainly of Vi antigen; an acetone-killed suspension of $E$. coli (MC8A); and Vi antigen prepared from $E$. coli by the procedure of Esposito and Feeley (1970). All induced high protection in mice against challenge with $S$. typhi. The protection rose sharply to a peak at 4 days and declined thereafter until by day 18 it had fallen to the level at day 2 . The sequence of events was virtually the same after vaccination with suspensions of $S$. typhi or E. coli. or of Vi extracts of either, and whether these were given intraperitoneally or subcutaneously.

TABLE III

Development of $V i$ and $O$ agglutinins in the sera of mice vaccinated intraperitoneally or subcutaneously with $S$. typhi or $E$. coli suspensions killed by heat-phenol or acetone

\begin{tabular}{|c|c|c|c|c|c|c|c|c|c|c|}
\hline \multirow{3}{*}{$\begin{array}{l}\text { Vaccine } \\
\text { batch }\end{array}$} & \multirow{3}{*}{$\begin{array}{l}\text { Type of } \\
\text { vaccine }\end{array}$} & \multirow{3}{*}{$\begin{array}{l}\text { Route of } \\
\text { injection }\end{array}$} & \multicolumn{8}{|c|}{$\begin{array}{l}\text { Agglutination titres of serum against Vi or } \\
O \text { antigen at indicated day after vaccination }\end{array}$} \\
\hline & & & \multicolumn{2}{|c|}{2 days } & \multicolumn{2}{|c|}{4 days } & \multicolumn{2}{|c|}{8 days } & \multicolumn{2}{|c|}{18 days } \\
\hline & & & Vi & O & Vi & 0 & Vi & O & Vi & O \\
\hline V980 & S. typhi, heat-killed & $\begin{array}{l}\text { SC } \\
\text { IP }\end{array}$ & $\begin{array}{l}4 \\
4\end{array}$ & $\cdots$ & $\begin{array}{l}64 \\
64\end{array}$ & 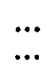 & $\begin{array}{l}8 \\
8\end{array}$ & $\begin{array}{l}0 \\
4\end{array}$ & $\begin{array}{l}1 \\
4\end{array}$ & $\begin{array}{l}16 \\
64\end{array}$ \\
\hline MSt33 & S. typhi, acetone-killed & $\begin{array}{l}\text { SC } \\
\text { IP }\end{array}$ & $\begin{array}{r}16 \\
4\end{array}$ & $\begin{array}{l}\cdots \\
\cdots\end{array}$ & $\begin{array}{r}64 \\
128\end{array}$ & $\cdots$ & $\begin{array}{l}4 \\
8\end{array}$ & $\begin{array}{l}\mathbf{0} \\
\mathbf{0}\end{array}$ & $\begin{array}{l}2 \\
4\end{array}$ & $\begin{array}{r}8 \\
128\end{array}$ \\
\hline MSt54 & S. typhi, acetone-killed & $\begin{array}{l}\text { SC } \\
\text { IP }\end{array}$ & $\begin{array}{l}4 \\
2\end{array}$ & $\begin{array}{l}\ldots \\
\cdots\end{array}$ & $\begin{array}{l}16 \\
64\end{array}$ & $\ldots$ & $\begin{array}{l}4 \\
4\end{array}$ & $\begin{array}{l}0 \\
0\end{array}$ & $\begin{array}{l}4 \\
4\end{array}$ & $\begin{array}{l}8 \\
8\end{array}$ \\
\hline MC8A & E. coli, acetone-killed & $\begin{array}{l}\text { SC } \\
\text { IP }\end{array}$ & $\begin{array}{l}2 \\
4\end{array}$ & $\ldots$ & $\begin{array}{l}128 \\
256\end{array}$ & $\ldots$ & $\begin{array}{r}2 \\
16\end{array}$ & $\begin{array}{l}0 \\
0\end{array}$ & $\begin{array}{l}1 \\
8\end{array}$ & $\begin{array}{l}0 \\
2\end{array}$ \\
\hline
\end{tabular}

$\mathrm{SC}=$ Subcutaneous; IP $=$ intraperitoneal $; \ldots=$ not done.

The similarity in the responses of all the preparations suggested the operation of a common factor. Vi antigen was the only factor known to link the preparations from E. coli (MC8A and XC90) and those from S. typhi (V980, MSt33, and XSt72). Because Landy (1957) found that the response to Vi antigen was virtually unaffected by the route of administration and that its level fluctuated little with time, we had suggested (Sterne and Trim, 1971) that the early peak was probably caused by non-specific factors. Against this were the observations that the preparations of Vi antigen (XSt72 and XC90) also showed the early peak although, presumably, devoid of factors likely to provoke a non-specific response.

Experiments were performed (summarised in table III) to determine whether the peak demonstrated in table II could be correlated with the development of Vi antibodies. Each of 20 mice was given a single inoculum, either intraperitoneally or subcutaneously, of a particular preparation, bled individually at the stated times, and aliquots of their sera pooled. These pools were tested for the presence of typhoid $\mathrm{Vi}$ and $\mathrm{O}$ agglutinins. 
The Vi agglutinins showed a peak at 4 days after intraperitoneal and after subcutaneous vaccination. This corresponded to the height of resistance to challenge. The $\mathbf{O}$ agglutinins, on the other hand, were virtually undetectable as late as the 8th day after vaccination, but had attained a considerable height by the 18th day. Thus only the Vi antibody showed any correlation with protection. The rise in $\mathrm{O}$ antibody corresponded with the decline in protection.

\section{Discussion}

Landy (1957) wrote: " the mouse protective-potency test for typhoid, as it is commonly performed, is for all practical purposes an assay for Vi antigen." But there is ample evidence that this antigen, so potent for inducing immunity in mice, is of little importance in the protection of man against typhoid. The alcoholised vaccine of Felix, formulated to contain $\mathrm{Vi}$ antigen, was discontinued after failure to protect in the field (Marmion, Naylor and Stewart, 1953). Vaccines prepared from purified Vi and $O$ antigens ("chemical vaccines") have consistently been less effective in field trials than typhoid suspensions killed by heat or acetone, despite their ability to induce the formation of high titres of Vi antibodies (Hejfets et al., 1968).

Nevertheless, the continued use of assay procedures involving the active immunisation of mice indicates a belief that the protection of mice is not due mainly to a response to Vi antigen. We showed (Sterne and Trim, 1971) that the protection in mice by killed suspensions of $S$. typhi Ty2 was indistinguishable, qualitatively and quantitatively, from that induced by a Viproducing strain of $E$. coli, and we concluded that this immunity was mainly due to Vi antibody. At the time, we thought that the high early peak of immunity shown by all the preparations tested might have been induced by non-specific mechanisms. But the same early peak occurred after immunisation with preparations consisting essentially of $\mathrm{Vi}$ antigen; moreover, the rise and fall of Vi agglutinins paralleled closely the rise and fall in protection in the case of heat-phenol- and acetone-killed suspensions. Thus, in mice at least, heat-phenol-killed vaccine was as effective as acetone-killed in eliciting the formation of $\mathrm{Vi}$ agglutinins. $\mathrm{O}$ antibodies could not be detected at the time when $\mathrm{Vi}$ antibodies and protection were at their height. The rise of $\mathrm{O}$ agglutinins corresponded with the period of declining protection and Vi titres.

Thus it seemed that protection after the SCM and the IPM procedures was mainly a response to Vi antigen. But the high maximum at $\mathbf{4}$ days did not conform to the pattern found by Landy and could have been due to the adjuvant effect of non-specific factors on the response to Vi antigen. Such a mechanism could also be invoked to explain the relatively greater protection elicited by acetone-killed suspensions of $S$. typhi and Vi-producing strains of $E$. coli when inoculated intraperitoneally. However, this would require that our preparations of $\mathrm{Vi}$ antigen from $S$. typhi and from E. coli were contaminated with such putative adjuvant factors. The negative correlation of $O$ antibody with protection suggests that endotoxin is unlikely to be responsible for such adjuvance. 
Because $\mathrm{Vi}$ antigen appears to play the predominant role in protecting mice against challenge, it is improbable that either the SCM or IPM procedures are discriminating enough to detect antigens likely to be significant in the protection of man.

\section{SUMMARY}

Protection of mice against challenge with virulent Salmonella typhi could be induced by intraperitoneal or subcutaneous vaccination with heat-phenolor acetone-inactivated suspensions of $S$. typhi strain Ty2 or of a Vi-producing strain of Escherichia coli, or with Vi antigen prepared from either of these.

In all cases, protection rose to a maximum at about 4 days after vaccination. By day 18 this had fallen to the level at day 2.

The rise and fall of $\mathrm{Vi}$ agglutinins in mice vaccinated either intraperitoneally or subcutaneously with heat-phenol- or with acetone-killed suspensions of $S$. typhi Ty2 or E. coli paralleled closely the rise and fall in protection, whereas the rise of $\mathrm{O}$ agglutinins corresponded with the decline in protection.

It was concluded that the potency tests for typhoid vaccines according to procedures SCM and IPM (WHO type-N procedures) in mice are chiefly a measure of the response to $\mathrm{Vi}$ antigen and consequently not a measure of factors responsible for eliciting immunity in man.

We are very much indebted to Mrs Eileen Ward for her interested and conscientious help throughout the work.

\section{REFERENCES}

Department of Health, Education and Welfare, USA 1969. Additional standards; typhoid vaccine and limits of potency. Federal Register, USA., 34, 8914.

Esposito, V. M. AND Feeley, J. C. 1970. Isolation of Vi antigen from Escherichia coli by a new method. Infect. Immun., 1, 69.

Hejfets, L. B., Levina, L. A., Bentsianova, T. G. ardo Salmin, L. V. 1968. The protective activity of various antigen complexes of typhoid and paratyphoid $B$ vaccines: controlled field trials and laboratory studies. Proc. 11th Int. Congr. Microb. Standard., Milan. In Prog. immunobiol. Standard. published by Karger, Basel, vol. 4, p. 561, 1970.

Joó, I., Pusztal, Z. AND Juhász, V. P. 1968. Mouse-protective ability of the International Reference Preparations of typhoid vaccine. $Z$. ImmunForsch. exp. Ther., 135, 365.

LANDY, M. 1957. Studies on Vi antigen. VII. Characteristics of the immune response in the mouse. Am. J. Hyg., 65, 81.

Marmion, D. E., Naylor, G. R. E. AND Stewart, I. O. 1953. Second attacks of typhoid fever. J. Hyg., Camb., 51, 260.

PITTMAN, M. AND BoHNER, H. J. 1966. Laboratory assays of different types of field trial typhoid vaccines and relationship to efficacy in man. J. Bact., 91, 1713.

STERNE, M. 1958. The growth of Brucella abortus strain 19 in aerated dialysed media. J. gen. Microbiol., 18, 747.

Sterne, M. AND TRIM, G. 1968. The effects of non-specific agents and route of administration on the biological assay of Salmonella typhi vaccines. Intern. Symp. Enterobact. Vaccines, Berne. In Symp. Series Immunobiol. Standard., published by Karger, Basel, vol.15, p. 93, 1971.

Sterne, M. AND TRIM, G. 1970. Enhancement of the potency of typhoid vaccines with calcium alginate. J. med. Microbiol., 3, 649.

STERNE, M. AND TRIM, G. 1971. The significance of protection tests in mice for evaluating typhoid vaccines. Proc. 12th Int. Congr. Microb. Standard., Annecy. In Prog. Immunobiol. Standard., published by Karger, Basel, vol. 5. p. 382, 1972. 